\title{
PENGARUH PENGGUNAAN KARTU PETUNJUK DALAM MODEL PEMBELAJARAN PROBLEM BASED LEARNING TERHADAP KEMAMPUAN PEMECAHAN MASALAH MATEMATIKA SISWA
}

\author{
Md. Swandewi, I. G. A. Mahayukti, I. N. Sukajaya \\ Jurusan Pendidikan Matematika, Universitas Pendidikan Ganesha \\ Singaraja, Indonesia \\ e-mail: madeswandewi@gmail.com, gustiayumahayukti@gmail.com, \\ nyoman.sukajaya@undiksha.ac.id
}

\begin{abstract}
Abstrak
Penelitian ini bertujuan untuk mengetahui apakah kemampuan pemecahan masalah matematika siswa yang mengikuti pembelajaran dengan model pembelajaran Problem Based Learning berbantuan kartu petunjuk lebih baik daripada kemampuan pemecahan masalah matematika siswa yang mengikuti pembelajaran konvensional. Populasi dalam penelitian ini adalah siswa kelas X SMAN 1 Sawan tahun ajaran 2016/2017 sebanyak 212 orang yang tersebar ke dalam 8 kelas. Dua kelas diambil sebagai sampel dengan teknik cluster random sampling. Salah satu kelas yang dipilih secara random digunakan sebagai kelompok eksperimen dan yang lainnya sebagai kelompok kontrol. Desain penelitian yang digunakan adalah post test only control group design. Data skor kemampuan pemecahan masalah matematika siswa diperoleh melalui tes kemampuan pemecahan masalah matematika. Hasil uji normalitas dan homogenitas varians menunjukkan bahwa skor berdistribusi normal dan tidak memiliki perbedaan varians. Data dianalisis dengan menggunakan uji-t satu ekor dengan taraf signifikansi $5 \%$. Hasil dari analisis data menunjukkan bahwa nilai dari thitung $=2,675$ lebih dari tabel $=1,6788$, ini berarti $\mathrm{H}_{0}$ ditolak. Artinya pada taraf signifikansi 5\%, kemampuan pemecahan masalah matematika siswa kelas X SMAN 1 Sawan yang mengikuti pembelajaran dengan model pembelajaran Problem Based Learning berbantuan kartu petunjuk lebih baik daripada kemampuan pemecahan masalah matematika siswa yang mengikuti pembelajaran konvensional.
\end{abstract}

Kata kunci: model pembelajaran Problem Based Learning, kartu petunjuk, kemampuan pemecahan masalah matematika

\begin{abstract}
This research aimed at investigating whether students' mathematical problem solving ability who learned through card-instructions-assisted Problem Based Learning model was better than students' mathematical problem solving ability who learned through conventional learning. This research was conducted to the tenth-grade students of SMAN 1 Sawan in the academic year 2016/2017, with 212 students as the population divided into eight classes. Two classes were taken as sample by cluster random sampling technique. One of the classes was randomly selected as an experimental group and other as control group. This research used post test only control group design. Data were collected with post test about mathematical problem solving ability. The normality and homogeneity of variance test result showed that the scores are normally distributed and homogenous in variance. The data were analyzed by using one tail t-test with significance level of $5 \%$. The result of data analysis showed that the value of t-test $=2.675$ greater than $\mathrm{t}$-table $=1.6788$, so that the null hypothesis is rejected. This means that at significance level of $5 \%$, the mathematical problem solving ability of students who learned through card-instructions-assisted Problem Based Learning model is better than the mathematical problem solving ability of students who learned through conventional learning.
\end{abstract}

Keywords: Problem Based Learning model, card instructions, mathematical problem solving ability 


\section{PENDAHULUAN}

Salah satu kemampuan matematis yang mutlak untuk dikembangkan di jenjang Sekolah Menengah Atas (SMA) adalah kemampuan pemecahan masalah. Kemampuan pemecahan masalah matematika merupakan kemampuan siswa dalam menyelesaikan suatu persoalan dengan menerapkan pengetahuan serta konsep-konsep yang telah dikuasai dalam matematika. Hudojo (2003) menyatakan bahwa dengan memiliki kemampuan pemecahan masalah, siswa dapat memahami suatu permasalahan, terampil dalam memilih dan mengidentifikasi kondisi dan konsep yang relevan, mencari generalisasi, merumuskan rencana penyelesaian dan mengorganisasikan keterampilan yang telah dimiliki sebelumnya. Sependapat dengan pernyataan tersebut, Hartono (2014), menyatakan bahwa pemecahan masalah merupakan bagian dari kurikulum matematika yang sangat penting dalam pembelajaran matematika karena siswa akan memperoleh pengalaman dalam menggunakan pengetahuan serta keterampilan yang dimiliki untuk menyelesaikan soal yang tidak rutin. Selain itu, NCTM (2010:1) menyatakan bahwa, "Problem solving plays an important role in mathematics and should have a prominent role in the mathematics education". Pendapat tersebut berarti bahwa pemecahan masalah memainkan peranan penting dalam matematika dan seharusnya mempunyai peranan utama dalam pendidikan matematika.

Mengingat pentingnya kemampuan pemecahan masalah matematika seperti yang diuraikan di atas, pendidikan di sekolah sebaiknya memfasilitasi siswa untuk mengembangkan kemampuan tersebut.Proses pembelajaran matematika di sekolah seharusnya merangsang siswa agar memiliki kemampuan pemecahan masalah, melibatkan siswa secara aktif dalam kegiatan pembelajaran dan siswa harus didorong untuk terlibat dalam kegiatan pemecahan masalah matematika agar mereka mampu memahami lebih lanjut arti dari pengetahuan yang diperoleh sehingga dapat menerapkannya dalam kehidupan nyata.
Namun, kenyataan di lapangan menunjukkan bahwa kegiatan pemecahan masalah dalam proses pembelajaran matematika belum dijadikan sebagai kegiatan utama (Suherman, 2003). Siswa hanya menghafal konsep dan kurang mampu menggunakan konsep tersebut jika menemui masalah dalam kehidupan nyata yang berhubungan dengan konsep yang dimiliki. Terlebih lagi, siswa kurang mampu menentukan masalah dan merumuskannya. Banyak kritik yang ditujukan pada cara guru mengajar yang terlalu menekankan pada penguasaan sejumlah informasi atau konsep belaka (Trianto, 2009). Pembelajaran matematika di sekolah umumnya masih bersifat prosedural. Sebagian besar materi pelajaran disampaikan secara langsung oleh guru dan untuk memantapkan pemahaman, siswa mengerjakan soal-soal latihan yang bersifat rutin. Pembelajaran yang masih berpusat pada guru (teachercentered) dan kebiasaan siswa menerima informasi dan pengetahuan dari guru menyebabkan siswa jarang dan bahkan tidak pernah melatih kemampuannya dalam hal memecahkan masalah matematika. Hal ini menunjukkan bahwa masih adanya kesenjangan (gap) antara harapan dengan kenyataan yang terjadi di lapangan.

Pembelajaran matematika yang kurang menekankan kegiatan pemecahan masalah inilah yang diduga menjadi penyebab kemampuan pemecahan masalah matematika siswa Indonesia masih dapat dikatakan tergolong rendah. Hal tersebut dapat dilihat dari hasil survei PISA (Programme for International Students Assessment) tahun 2015. Dari hasil tes dan evaluasi PISA 2015 diperoleh informasi bahwa performa siswa-siswi Indonesia masih tergolong rendah. Berturut-turut rata-rata skor pencapaian siswa-siswi Indonesia untuk sains, membaca, dan matematika berada di peringkat 62,61 , dan 63 dari 69 negara yang dievaluasi (www.ubaya.ac.id). Khusus untuk matematika, Indonesia hanya mampu memperoleh rata-rata skor 386. Rata-rata skor yang diperoleh Indonesia tersebut masih berada di bawah rata-rata skor PISA yakni 490 
(www.oecd.org). Salah satu faktor yang menjadi penyebab dari rendahnya performa siswa Indonesia dalam PISA, khususnya untuk matematika yakni karena lemahnya kemampuan pemecahan masalah siswa dalam menyelesaikan soalsoal non rutin atau level tinggi.

Untuk menyikapi hal tersebut dan untuk meningkatkan kualitas proses dan hasil belajar, para ahli pembelajaran telah menyarankan penggunaan paradigma pembelajaran konstruktivistik untuk kegiatan pembelajaran di kelas. Salah satu model pembelajaran yang sesuai dengan pembelajaran konstruktivis dan sesuai untuk digunakan dalam memaksimalkan kemampuan pemecahan masalah matematika siswa adalah model pembelajaran Problem Based Learning (PBL).

PBL merupakan salah satu model pembelajaran inovatif yang dapat memberikan kondisi belajar aktif kepada siswa, yakni suatu model pembelajaran yang melibatkan siswa untuk memecahkan suatu masalah melalui tahap-tahap metode ilmiah sehingga siswa dapat mempelajari pengetahuan yang berhubungan dengan masalah tersebut dan sekaligus memiliki keterampilan untuk memecahkan masalah (Ngalimun, 2016:117).

Hasil penelitian Kartiwi (2011) menunjukkan bahwa terdapat perbedaan prestasi belajar matematika antara siswa yang mengikuti model pembelajaran berbasis masalah dan siswa yang mengikuti model pembelajaran konvensional. Berdasarkan perhitungan statistik didapat bahwa prestasi belajar matematika siswa yang mengikuti model pembelajaran $\mathrm{PBL}$ memiliki skor rata-rata sebesar 80,8, lebih tinggi daripada prestasi belajar matematika siswa yang mengikuti model pembelajaran konvensional yang memiliki skor rata-rata sebesar 74,7. Adapun juga hasil penelitian Amelia (2014) menunjukkan bahwa adanya peningkatan hasil belajar matematika siswa melalui penerapan model pembelajaran PBL.

Berdasarkan uraian di atas dapat dikemukakan bahwa PBL sebaiknya digunakan dalam pembelajaran karena: 1 ) dengan PBL akan terjadi pembelajaran bermakna, 2) dalam situasi PBL, siswa mengintegrasikan pengetahuan dan keterampilan secara simultan dan mengaplikasikannya dalam konteks yang relevan, dan 3) PBL dapat meningkatkan kemampuan berpikir kritis, menumbuhkan inisiatif siswa dalam bekerja, motivasi internal untuk belajar, dan dapat mengembangkan hubungan interpersonal dalam bekerja kelompok.

Akan tetapi dalam prakteknya, model PBL masih menemui beberapa kendala, seperti masih banyak siswa yang kesulitan dalam hal memahami masalah, siswa masih sulit dalam memulai langkah awal yang harus dilakukan apabila diberikan suatu masalah, serta masih tampak siswa kurang terlibat langsung dalam kegiatan pembelajaran. Ketika siswa diberikan suatu permasalahan, ia berpotensi mengalami kesulitan untuk memahami dan menganalisis apa maksud dari permasalahan yang disajikan oleh guru dan merencanakan strategi penyelesaiannya. Kemampuan siswa dalam memahami masalah dan merencanakan penyelesaian merupakan langkah awal dalam hal pemecahan masalah. Apabila siswa tidak mampu dalam memahami masalah dan membuat rencana tentunya akan berdampak pada pemecahan masalah yang keliru atau kurang tepat. Suherman, dkk. (2003) menyatakan bahwa, guru menghadapi kesulitan dalam mengajarkan bagaimana cara menyelesaikan masalah dengan baik, di lain pihak siswa menghadapi kesulitan bagaimana menyelesaikan masalah yang diberikan guru. Berbagai kesulitan ini muncul antara lain karena mencari jawaban dipandang sebagai satu-satunya tujuan yang ingin dicapai. Karena hanya berfokus pada jawaban, siswa seringkali salah dalam memilih teknik penyelesaian yang sesuai.

Menyikapi hal tersebut, dalam hal ini guru harus menyiasati pembelajaran dengan menerapkan suatu bantuan berupa media pembelajaran. Dengan adanya media pembelajaran diharapkan mampu untuk membantu siswa dalam hal memahami masalah dan menyusun rencana penyelesaian, sehingga siswa 
mampu menumbuhkan kembali rasa ingin tahunya dan mencoba kembali dalam memahami permasalahan maupun dalam hal membuat rencana penyelesaiannya.

Penelitian terkait penggunaan media pembelajaran dalam model pembelajaran PBL sudah banyak dilakukan, seperti penggunaan kartu soal ataupun kartu kerja. Namun, sepanjang pengetahuan penulis, penggunaan kartu petunjuk belum pernah diterapkan dalam pembelajaran. Oleh karena itu, pembelajaran PBL dapat dibantu dengan adanya penggunaan media berupa kartu petunjuk. Kartu petunjuk yang dimaksud dalam penelitian ini adalah suatu sarana untuk membantu siswa dalam menyelesaikan permasalahan, yang berisikan petunjuk untuk melakukan sesuatu. Kartu petunjuk dalam penelitan ini hanya memuat instruksi berupa petunjuk-petunjuk yang diharapkan dapat memudahkan siswa dalam langkah pemecahan masalah, utamanya dalam langkah memahami masalah dan merencanakan penyelesaian. Jadi, dalam kartu petunjuk tidak lagi berisi tugas ataupun permasalahan baru yang harus diselesaikan oleh siswa, seperti halnya pada kartu kerja. Siswa diharapkan dapat menemukan konsep atau strategi yang relevan untuk memecahkan permasalahan yang diberikan melalui petunjuk yang disajikan secara tertulis pada kartu tersebut. Melalui tahapan-tahapan model pembelajaran $\mathrm{PBL}$ berbantuan kartu petunjuk inilah siswa diharapkan akan mampu mengembangkan kemampuan pemecahan masalahnya.

Berdasarkan pemaparan terkait model pembelajaran inovatif yang berkenaan dengan upaya meningkatkan kemampuan pemecahan masalah matematika dan sepanjang pengetahuan penulis belum memadainya referensi atau hasil penelitian yang mengkaji terkait penggunaan kartu petunjuk dalam pembelajaran PBL terhadap kemampuan pemecahan masalah matematika siswa, penulis tertarik dan memandang perlu melakukan penelitian yang berjudul "Pengaruh Model Pembelajaran Problem Based Learning Berbantuan Kartu Petunjuk Terhadap Kemampuan

\section{Pemecahan Masalah Matematika Siswa di SMAN 1 Sawan".}

Penelitian ini bertujuan untuk mengetahui apakah kemampuan pemecahan masalah matematika siswa yang mengikuti pembelajaran dengan model pembelajaran Problem Based Learning berbantuan kartu petunjuk lebih baik daripada kemampuan pemecahan masalah matematika siswa yang mengikuti pembelajaran konvensional.

\section{METODE}

Desain penelitian yang digunakan dalam penelitian ini adalah Post Test Only Control Group Design. Populasi dalam penelitian ini adalah siswa kelas $X$ SMAN 1 Sawan tahun ajaran 2016/2017 sebanyak 212 orang yang tersebar ke dalam 8 kelas yaitu kelas $X 1, X 2, X 3, X$ $4, \times 5, \times 6, \times 7$, dan X 8. Penentuan sampel dalam penelitian ini dilakukan dengan teknik cluster random sampling, di mana setiap kelas memiliki kesempatan yang sama untuk dipilih sebagai sampel.

Sebelum menentukan kelompok kontrol dan kelompok eksperimen, dilakukan uji kesetaraan terhadap sampel menggunakan data nilai rapor mata pelajaran matematika siswa kelas $X$ semester ganjil tahun ajaran 2016/2017. Setelah dilakukan uji kesetaraan terhadap kelompok sampel dan diperoleh hasil bahwa kelompok sampel setara, dilakukan pengundian untuk menentukan kelompok kontrol dan kelompok eksperimen. Dari hasil pengundian, diperoleh bahwa kelas $X 1$ sebagai kelompok eksperimen dan kelas X 2 sebagai kelompok kontrol. Kelompok kontrol adalah kelompok yang mengikuti pembelajaran dengan pembelajaran konvensional, sedangkan kelompok eksperimen adalah kelompok yang mengikuti pembelajaran dengan model pembelajaran Problem Based Learning berbantuan kartu petunjuk.

Variabel bebas pada penelitian ini adalah model pembelajaran yang diterapkan yaitu model pembelajaran Problem Based Learning berbantuan kartu petunjuk yang diterapkan pada kelompok eksperimen dan model pembelajaran konvensional yang diterapkan pada kelas kontrol. Variabel terikat pada penelitian ini 
adalah kemampuan pemecahan masalah matematika siswa.

Instrumen yang digunakan untuk mengumpulkan data kemampuan pemecahan masalah matematika siswa adalah tes kemampuan pemecahan masalah matematika yang berbentuk tes uraian. Instrumen yang telah dibuat selanjutnya diuji validitas isinya melalui dua orang pakar untuk menguji apakah tes yang dibuat relevan atau tidak. Kemudian dilanjutkan dengan uji coba instrumen dan hasil uji coba tersebut dianalisis validitas dan reliabilitasnya.

Untuk menguji validitas butir soal uraian digunakan rumus koefisien korelasi product-moment dari Carl Pearson. Sedangkan untuk uji reliabilitasnya digunakan rumus Alpha Cronbach.

Data yang diperoleh dari penelitian ini adalah data kuantitatif berupa skor kemampuan pemecahan masalah matematika siswa. Sebelum melakukan pengujian hipotesis, terlebih dahulu dilakukan uji prasyarat yaitu uji normalitas dan uji homogenitas. Untuk menguji normalitas sebaran data digunakan uji Lilliefors, sedangkan untuk uji Tabel 1. Hasil Analisis Data Kemampuan Pemecahan Masalah Matematika Siswa

\begin{tabular}{cccc}
\hline No & Variabel & Kelompok Kontrol & Kelompok Eksperimen \\
\hline 1 & Banyak siswa & 25 & 25 \\
2 & Rata-rata & 40,76 & 46,36 \\
3 & Varians & 45,02 & 64,57 \\
4 & Standar deviasi & 6,71 & 8,04 \\
5 & Median & 43 & 49 \\
6 & Modus & 32 & $55 \& 44$ \\
7 & Range & 20 & 29 \\
8 & Maksimum & 52 & 55 \\
9 & Minimum & 32 & 26 \\
\hline
\end{tabular}

Berdasarkan Tabel 1 terlihat bahwa rata-rata skor kemampuan pemecahan masalah matematika siswa kelompok kontrol adalah 40,76, sedangkan rata-rata skor kemampuan pemecahan masalah matematika siswa kelompok eksperimen adalah 46,36. Berdasarkan perhitungan tersebut, rata-rata skor kemampuan pemecahan masalah matematika siswa pada kelompok eksperimen lebih tinggi daripada rata-rata skor kemampuan homogenitas varians digunakan uji Levene.

Berdasarkan uji prasyarat yang telah dilakukan, diperoleh hasil bahwa skor kemampuan pemecahan masalah matematika siswa berdistribusi normal dan memiliki varians yang homogen. Selanjutnya dilakukan pengujian hipotesis menggunakan uji-t satu ekor (ekor kanan) dengan taraf signifikansi $5 \%$ untuk mengetahui apakah kemampuan pemecahan masalah matematika siswa yang mengikuti pembelajaran dengan model pembelajaran Problem Based Learning berbantuan kartu petunjuk lebih baik daripada kemampuan pemecahan masalah matematika siswa yang mengikuti pembelajaran konvensional.

\section{HASIL DAN PEMBAHASAN}

Hasil analisis data mengenai skor kemampuan pemecahan masalah matematika siswa yang diperoleh dari post test yang diberikan kepada kedua kelompok sampel dapat dilihat pada tabel 1 berikut. pemecahan masalah matematika siswa pada kelompok kontrol.

Hasil uji normalitas skor kemampuan pemecahan masalah matematika siswa dapat dilihat pada Tabel 2 . 
Tabel 2. Rangkuman Hasil Uji Normalitas Skor Kemampuan Pemecahan Masalah Matematika

\begin{tabular}{llccc}
\hline No & Kelas Sampel & $\mathbf{L}_{\text {hitung }}$ & $\mathbf{L}_{\text {tabel }}$ & Keterangan \\
\hline 1 & Kontrol & 0,1611 & \multirow{2}{*}{0,1726} & Normal \\
2 & Eksperimen & 0,1401 & & Normal \\
\hline
\end{tabular}

Berdasarkan Tabel 2 dapat dilihat bahwa Lhitung untuk kelompok kontrol adalah 0,1611 dan Lhitung untuk kelompok eksperimen adalah 0,1401 . $L_{\text {tabel }}$ diperoleh dari tabel Lilliefors dengan $n=25$ dan taraf signifikan $5 \%$, sehingga diperoleh $L_{\text {tabel }}=0,1726$. Hal ini menunjukkan bahwa Lnitung untuk kedua kelompok kurang dari $L_{\text {tabel, }}$ oleh karena itu Ho diterima. Artinya pada taraf signifikan $5 \%$, data skor kemampuan pemecahan masalah matematika siswa kelompok kontrol dan kelompok eksperimen berasal dari populasi yang berdistribusi normal.

Dari hasil uji homogenitas varians dengan menggunakan uji Levene, diperoleh bahwa nilai $W_{\text {hitung }}=0,066$ dan nilai $F_{\text {tabel }}=4,042$. Apabila dibandingkan, nilai $W_{\text {hitung }}$ kurang dari nilai $F_{\text {tabel. }}$. Dengan demikian $\mathrm{H}_{0}$ diterima, artinya pada taraf signifikan $5 \%$ data kelompok eksperimen dan kelompok kontrol memiliki varians yang homogen.

Berdasarkan uji normalitas dan uji homogenitas, diketahui bahwa data dari kelompok eksperimen dan kelompok kontrol berdistribusi normal dan homogen.
Oleh sebab itu dapat dilakukan pengujian hipotesis dengan menggunakan uji-t satu ekor. Adapun hipotesis yang diuji pada penelitian ini adalah sebagai berikut.

$H_{0}: \mu_{1}=\mu_{2}$

yaitu tidak terdapat perbedaan kemampuan pemecahan masalah matematika siswa yang mengikuti pembelajaran dengan model pembelajaran Problem Based Learning berbantuan kartu petunjuk dengan kemampuan pemecahan masalah matematika siswa yang mengikuti pembelajaran konvensional

$H_{1}: \mu_{1}>\mu_{2}$

yaitu kemampuan pemecahan masalah matematika siswa yang mengikuti pembelajaran dengan model pembelajaran Problem Based Learning berbantuan kartu petunjuk lebih baik dari kemampuan pemecahan masalah matematika siswa yang mengikuti pembelajaran konvensional

Rangkuman hasil uji hipotesis dapat dilihat pada Tabel 3.

Tabel 3. Rangkuman Hasil Uji-t Skor Kemampuan Pemecahan Masalah Matematika

\begin{tabular}{cccccccc}
\hline Kelompok & $\mathrm{n}$ & $\bar{Y}$ & $\mathrm{~s}^{2}$ & $\mathrm{~S}$ & $s_{\text {gabungan }}^{2}$ & $t_{\text {hitung }}$ & $t_{\text {tabel }}$ \\
\hline Eksperimen & 25 & 46,36 & 64,5733 & 8,0358 & & & \\
Kontrol & 25 & 40,76 & 45,0233 & 6,7099 & & & \\
\hline
\end{tabular}

Berdasarkan Tabel 3 diperoleh nilai $t_{\text {hitung }}=2,675$. Adapun nilai $t_{\text {tabel }}$ pada taraf signifikansi $5 \%$ dan derajat kebebasan 48 adalah 1,6788. Apabila dibandingkan, nilai $t_{\text {hitung }}>t_{\text {tabel }}$. Dengan demikian, $\mathrm{H}_{0}$ ditolak dan $\mathrm{H}_{a}$ diterima. Artinya pada taraf signifikan $5 \%$, dugaan bahwa kemampuan pemecahan masalah matematika siswa yang mengikuti pembelajaran dengan model pembelajaran Problem Based Learning berbantuan kartu petunjuk lebih baik dari kemampuan pemecahan masalah matematika siswa yang mengikuti pembelajaran konvensional dapat diterima. 
Kemampuan pemecahan masalah matematika siswa yang mengikuti pembelajaran dengan model pembelajaran $\mathrm{PBL}$ berbantuan kartu petunjuk lebih baik daripada kemampuan pemecahan masalah matematika siswa yang mengikuti pembelajaran konvensional disebabkan karena pada model pembelajaran PBL siswa berkesempatan untuk lebih berpartisipasi aktif dalam kegiatan diskusi kelas, mempresentasikan hasil diskusi, dan mengonstruksi sendiri pengetahuan yang dimilikinya. Model pembelajaran PBL dirancang untuk membantu siswa mencapai tujuan pembelajaran yang mengedepankan kegiatan kemampuan pemecahan masalah matematika sebagai pokok pembelajaran. Oleh karenanya, siswa tidak semata-mata diarahkan untuk menemukan jawaban yang benar, tetapi bagaimana siswa bisa memahami, merencanakan, melaksanakan dan mengevaluasi seluruh proses dalam kegiatan pembelajaran.

Keaktifan siswa sangat berperan penting dalam meningkatkan kemampuan pemecahan masalah matematika, karena melalui keaktifan mendengar, menyimak, bertanya, berdiskusi, dan mengaplikasikan pengetahuan yang didapat dengan cara mengajarkannya pada orang lain, siswa akan mampu memahami materi pelajaran hingga pada akhirnya ia akan mampu menyelesaikan permasalahan yang diberikan. Tidak hanya itu, pada model pembelajaran PBL, siswa juga diarahkan untuk menemukan sendiri konsep-konsep matematika dari masalah matematika yang ada kaitannya dengan kehidupan sehari-hari, sehingga siswa termotivasi untuk mengarahkan dirinya sendiri dan mengaitkan konsep-konsep yang relevan dalam menyelesaikan masalah tersebut.

Untuk

pembelajaran dengan mengoptimalkan pembelajaran PBL, proses pembelajaran dibantu dengan suatu media pembelajaran berupa kartu petunjuk, yang diharapkan memiliki potensi besar untuk meningkatkan kualitas pembelajaran. Pembelajaran di kelas dimulai dengan guru memberikan permasalahan nyata terkait materi trigonometri yang sedang dipelajari oleh siswa. Permasalahanpermasalahan yang diajukan oleh guru tersebut selanjutnya terdapat pada LKS yang nantinya siswa secara berkelompok memecahkan masalah tersebut. Masalah yang terdapat pada LKS akan menuntut siswa untuk mengonstruksi pemikiran mereka guna memecahkan atau menyelesaikan permasalahan yang diberikan. Namun, sebelum siswa menyelesaikan permasalahan tersebut, terlebih dahulu siswa diajak untuk mempelajari materi melalui adanya kegiatan menemukan dan memahami rumus-rumus dan konsep trigonometri. Setelah siswa mampu menyelesaikan dan memahami kegiatan tersebut barulah siswa diajak untuk menyelesaikan permasalahan-permasalahan yang terkait dengan rumus-rumus atau konsep-konsep trigonometri yang telah mereka pahami.

Pembelajaran dengan menggunakan model pembelajaran PBL mengharuskan siswa untuk terbiasa bekerja dan berdiskusi dalam kelompok. Melalui berinteraksi dan berdiskusi, siswa dapat mengeluarkan ide-ide dalam menyelesaikan permasalahan matematika. Pada saat kegiatan diskusi kelompok, siswa dapat menggunakan kartu petunjuk yang diberikan oleh guru, yang berisi clue atau petunjuk singkat terkait konsep-konsep relevan yang dapat membantu siswa memecahkan masalah. Melalui adanya kartu petunjuk tersebut siswa akan mengingat kembali pengetahuan-pengetahuan sebelumnya yang relevan dalam menyelesaikan permasalahan dan siswa akan belajar secara mandiri untuk memecahkan masalah tersebut.

$$
\text { Peran guru dalam proses }
$$
pembelajaran hanyalah sebagai fasilitator. Jadi, siswa yang lebih aktif dalam kegiatan pembelajaran. Guru hanya membimbing siswa dalam menyelesaikan permasalahan yang diberikan. Bantuan yang diberikan guru kepada siswa berupa penggunaan kartu petunjuk apabila mereka mengalami kesulitan ataupun keraguan dalam menyelesaikan permasalahan yang ada pada LKS. Namun, apabila siswa masih mengalami kesulitan setelah menggunakan kartu 
petunjuk, maka guru akan melakukan bimbingan secara individual ataupun bimbingan kelompok.

Dalam proses pembelajaran, siswa menyelesaikan permasalahan un diberikan tetapi juga menyajikan hasil diskusi mereka terkait permasalahan pada LKS. Sehingga antara kelompok siswa yang satu dengan yang lainnya dapat saling bertukar pendapat atau pemikiran. Biasanya siswa yang ditunjuk merupakan siswa yang tergolong kemampuan pemecahan masalah matematikanya rendah. Hal ini bertujuan agar seluruh siswa mau aktif belajar di kelas serta mampu menguasai materi pelajaran yang diberikan. Guru dalam hal ini juga membantu siswa dalam merefleksi proses pembelajaran yang telah dilaksanakan, membantu siswa menyimpulkan materi yang telah dipelajari dan memberikan kesempatan kepada siswa untuk menyelesaikan permasalahan yang belum terjawab sebagai bahan latihan di rumah.

Keunggulan model pembelajaran Problem Based Learning berbantuan kartu petunjuk dibandingkan dengan pembelajaran konvensional adalah model pembelajaran PBL dapat melatih kecakapan siswa dalam menyelesaikan permasalahan yang berkaitan dengan kehidupan sehari-hari mereka. Masalah matematika yang diberikan akan menuntut siswa untuk membangun sendiri pengetahuannya melalui penyelidikan sampai menemukan penyelesaian dari masalah yang diberikan. Selain itu, penggunaan kartu petunjuk dalam proses pembelajaran akan memudahkan siswa dalam memahami masalah dan merencanakan penyelesaian masalah. Melalui kartu petunjuk ini siswa secara mandiri dapat mengaitkan konsep-konsep yang baru didapat dengan konsep-konsep relevan lainnya yang sudah mereka dapatkan sebelumnya.

Dari pengamatan selama proses penelitian dengan menggunakan model pembelajaran PBL berbantuan kartu petunjuk dapat diamati bahwa siswa lebih terbantu dalam hal memahami permasalahan matematika yang diberikan dan siswa lebih mudah dalam memahami konsep-konsep matematika yang diberikan, karena masalah yang diberikan berkaitan dengan kehidupan keseharian mereka. Berdasarkan hasil pengamatan selama kegiatan penelitian, proses pembelajaran dengan menggunakan model pembelajaran PBL berbantuan kartu petunjuk memperlihatkan siswa semakin berani untuk memberikan respon balik dari pertanyaan yang ada pada LKS. Respon balik ini berupa siswa semakin berani memberikan tanggapan atas pertanyaan arahan dari guru maupun menanggapi pendapat teman, mengajukan pertanyaan atas apa yang belum dimengerti dan semakin aktif untuk mengungkapkan masalah yang ada pada LKS dengan kata-katanya sendiri.

Ditinjau dari segi interaksi siswa pada saat pembelajaran, suasana kelas eksperimen lebih kondusif terutama pada saat kegiatan diskusi dan siswa mulai mempunyai kesadaran untuk memberikan kesempatan temannya yang kurang mampu untuk bergabung dalam kegiatan diskusi, bahkan untuk mewakili kelompok menyajikan hasil diskusi. Selain itu, jika ditinjau dari kegiatan belajar, aktivitas siswa yang mengikuti model pembelajaran PBL berbantuan kartu petunjuk lebih aktif dan antusias dalam belajar. Hal ini tidak terlepas dari setting pembelajaran yang memberikan kesempatan kepada siswa untuk berdiskusi dan mencoba-coba strategi yang ada di pikirannya dalam menyelesaikan permasalahan.

Pemaparan di atas menunjukkan bahwa penerapan model pembelajaran PBL berbantuan kartu petunjuk telah mampu memberikan kontribusi positif terhadap kemampuan pemecahan masalah matematika. Oleh karena itu, diharapkan model pembelajaran berbantuan kartu petunjuk ini dapat menjadi salah satu alternatif pembelajaran yang kreatif dan inovatif dalam upaya meningkatkan mutu pendidikan khususnya diterapkan dalam pembelajaran matematika.

Namun, meskipun sudah banyak hal positif yang dikemukakan, dalam pelaksanaannya, model pembelajaran PBL berbantuan kartu petunjuk tidak luput dari kendala yang dapat diuraikan sebagai 
berikut. 1) siswa pada awal-awal pembelajaran sering mengalami kesulitan dalam memecahkan masalah matematika yang diberikan karena memang mereka tidak terbiasa mengerjakan masalahmasalah non rutin. Siswa cepat bingung ketika dihadapkan dengan soal berbentuk cerita apalagi jika komponen diketahui dan ditanyakan tidak ditulis secara jelas pada soal. Hal ini dikarenakan buku siswa dan LKS yang dimiliki siswa tidak merangsang aktivitas berpikir lebih pada siswa. Siswa dengan mudah dapat mengerjakan soalsoal rutin yang ada pada buku LKS karena biasanya hanya diperlukan 1 prosedur saja. Dalam menyelesaikan permasalahan siswa juga belum terbiasa menyelesaikan permasalahan matematika menggunakan langkah-langkah yang terstruktur dalam pemecahan masalah matematika seperti menuliskan apa yang diketahui dari masalah dan apa yang hendak dicari, membuat rencana pemecahan masalah dengan cara membuat rumus atau membuat langkah penyelesaiannya, melakukan perencanaan penyelesaian masalah, serta memeriksa kembali penyelesaiaanya dengan cara membuat simpulan.

Untuk mengatasi hal tersebut, guru memberikan penjelasan dan pemahaman kepada siswa. Siswa dituntun dan dibiasakan agar dalam menyelesaikan soal pemecahan masalah matematika untuk menuliskan setiap tahapan pemecahan masalah matematika secara sistematis dan lengkap, mulai dari diketahui, ditanya, rencana penyelesaian atau rumus yang digunakan, penyelesaian masalah, dan simpulan. Pada tahap memeriksa kembali, guru selalu mengingatkan siswa untuk memeriksa kembali jawabannya dan mewajibkan siswa untuk menuliskan jawaban dalam bentuk kalimat lengkap berupa simpulan. Hal ini akan memacu mereka melihat kembali masalah dan apa yang ditanyakan, sehingga ini akan membantu dalam mendeteksi suatu kesalahan (Suteja, 2014). Hal ini juga didukung oleh Vardeman, D. (2011) dalam rubrik kemampuan pemecahan masalahnya yang menunjukkan bahwa indikator siswa dalam memeriksa kembali adalah menyimpulkan dan menafsirkan temuannya secara logis dan jelas dalam memecahkan masalah. Siswa juga dibimbing untuk membuat model matematika, gambar dan lain sebagainya yang dapat membantu mereka dalam menyelesaikan soal. Apabila siswa mengalami kendala dalam memahami masalah dan merencanakan penyelesaian siswa dapat menggunakan kartu petunjuk dan bila siswa masih mengalami keraguan, guru akan membimbing secara individual maupun kelompok. 2) alokasi waktu pembelajaran dengan menggunakan model pembelajaran PBL berbantuan kartu petunjuk relatif lama. Siswa membutuhkan waktu yang cukup lama untuk memahami masalah dan merencanakan penyelesaian masalah, sehingga waktu yang seharusnya digunakan untuk menjawab semua permasalahan menjadi berkurang. Namun, hal tersebut dapat diatasi dengan cara membagi tugas pada masing-masing kelompok. Jadi, setiap kelompok bertanggung jawab pada 1 masalah yang ada pada LKS dan mereka wajib mempresentasikannya agar teman di kelompok lain juga dapat menyelesaikan permasalahan yang sama. Apabila waktu pengerjaan LKS masih kurang dan masih ada masalah yang belum terselesaikan guru meminta siswa untuk melanjutkannya di rumah sebagai bahan latihan dan pertemuan berikutnya akan dibahas kembali.

\section{PENUTUP}

Berdasarkan hasil penelitian dan pembahasan yang telah diuraikan pada bab sebelumnya dapat disimpulkan bahwa terdapat pengaruh positif model pembelajaran Problem Based Learning berbantuan kartu petunjuk terhadap kemampuan pemecahan masalah matematika siswa. Hal tersebut ditunjukkan dari hasil post-test yang telah dianalisis, yakni diperoleh nilai thitung adalah 2,675 dan nilai tabel adalah 1,6788 yang menunjukkan bahwa $t_{\text {hitung }}>t_{\text {tabel. }}$. Dengan demikian kemampuan pemecahan masalah matematika siswa yang mengikuti pembelajaran dengan model pembelajaran Problem Based 
Learning berbantuan kartu petunjuk lebih baik dibandingkan kemampuan pemecahan masalah matematika siswa yang mengikuti pembelajaran konvensional.

Adapun saran yang dapat peneliti sampaikan adalah

a. Peneliti lain disarankan agar mengujicobakan pengaruh model ini pada aspek pembelajaran yang berbeda, misalnya kemampuan penalaran dan kemampuan berpikir kritis

b. Kepada praktisi pendidikan matematika, khususnya guru mata pelajaran matematika diharapkan dalam pembelajaran di kelas untuk menerapkan model pembelajaran Problem Based Learning berbantuan kartu petunjuk dalam pembelajaran di kelas sebagai salah satu alternatif pembelajaran mengingat pengaruh positif yang diberikan model pembelajaran ini terhadap kemampuan pemecahan masalah matematika siswa.

\section{DAFTAR RUJUKAN}

Hartono, Dr. Yusuf. 2014. Matematika; Strategi Pemecahan Masalah. Yogyakarta: Graha IImu.

Hudojo, H. 2003. Pengembangan Kurikulum dan Pembelajaran Matematika. Malang: JICA.

Iswadi, Hazrul. 2016. Sekelumit dari Hasil PISA 2015 yang Baru Dirilis. Tersedia pada: http//www.ubaya.ac.id/2014/content/ articles_details/230/Sekelumit-DariHasil-PISA-2015-Yang-Baru-

Dirilis.html. Diakses, 10 Januari 2017.

Kartiwi, Desak Putu. 2011. "Pengaruh Pembelajaran Berbasis Masalah Ditinjau dari Bakat Numerik dan Kecemasan Siswa Terhadap Prestasi Belajar Matematika Siswa Kelas X SMA Negeri 1 Kuta". Ejournal Program Pasca Sarjana Universitas Pendidikan Ganesha Singaraja. Vol.7 No. 2.
NCTM, 2010. Why is Teaching With Problem Solving Important to Student Learning?. USA: NCTM, Inc.

Ngalimun. 2016. Strategi dan Model Pembelajaran. Yogyakarta: Aswaja Pressindo.

OECD. 2016. PISA 2015 Results in Focus. Tersedia pada: https://www.oecd.org/pisa/pisa2015-results-in-focus.pdf. Diakses, 10 Januari 2017.).

Suherman, Erman dkk. 2003. Strategi Pembelajaran Matematika Kontemporer. Bandung: JICA

Suteja, I G.L. 2014. Implementasi Model Pembelajaran Pemecahan Masalah dengan Metode Means-Ends Analysis (MEA) untuk Meningkatkan Kemampuan Pemecahan Masalah dan Kepercayaan Diri Siswa Kelas VIII B1 SMP Negeri 4 Singaraja. Skripsi (tidak diterbitkan). Singaraja: UNDIKSHA.

Trianto. 2009. Mendesain Model Pembelajaran Inovatif Progresif : Konsep, Landasan, dan Implementasinya pada Kurikulum Tingkat Satuan Pendidikan. Jakarta: Kencana Prenada Media Group.

Vardeman, D. 2011. Problem Solving Skills Rubric. United States: University of Southern Maine. 